\title{
Variation of Tidal Range Based on Hijra Calendar And Its Relation With Ethno-Oceanography of the Sama Tribe in Eastern Indonesia
}

\author{
Salnuddin ${ }^{1 *}$, I Wayan Nurjaya ${ }^{2}$, Indra Jaya² and Nyoman M.N. Natih ${ }^{2}$ \\ ${ }^{1}$ Marine Science Study Program, Faculty of Fisheries and Marine Sciences, University of Khairun \\ Jl. Raya Gambesi Kecamatan Kota Ternate Selatan, Ternate, North Maluku, Indonesia 97719 \\ ${ }_{2}^{2}$ Marine Science and Technology Department, Faculty of Fisheries and Marine Sciences \\ Bogor Agricultural University \\ Jl. Agatis, Kampus IPB Dramaga Bogor Indonesia 16680 \\ Email:Sal_Unkhair@Yahoo.co.id
}

\begin{abstract}
Based on Ethno-Oceanography of the Sama tribe in Eastern Indonesia, they measured and determined tidal range when Sha'ban taking place. Why do they do perform measurements other Hijra month? The questions and objective of this study were intended to respond the scientific fundamental of Ethno-Oceanography of the Sama tribe, by way of comparing the tidal range in Sha'ban with other month. The determination of tidal range using amplitude value of tidal constituents in accordance with the empirical equation from the Intergovernmental Committee of Surveying and Mapping - Permanent Committee on Tides and Mean Sea Level (ICSM PCTMSL). Determination of tidal constituent value (amplitude) used the T-Tide. The difference of tidal range upon each month of Hijra is calculated in statistical (Two way - ANOVA). Analysis results showed that the tidal range at Sha'ban was higher and the deviation was lower than the other months, other than that the diurnal constituent $\left(M_{2}, S_{2}\right.$ and $\left.K_{2}\right)$ in Sha'ban has maximum amplitude, Moreover, ANOVA results showed that Sya'ban was significantly different $(P<0.05)$ on Highest High Water Level $(H H W L)$ throughout Hijra month.
\end{abstract}

Keywords: Sama tribe, Sya'ban, Hijra calendar, T-Tide and tidal constituent

\section{Introduction}

It has been well documented that the tidal motions dominantly influenced by the Moon's rotation around the Earth. In addition, the tidal amplitude is also influenced by the Sun and Moon position to the earth, both of them rotate around its corresponding orbit causing its distance from the Earth becomes variable (Butikov, 2002; Souchay et al., 2013). Variation of the Sun and Moon position to the Earth influences the varied tidal force resultant creating special character in the Universe. One of the special characters is the Sun and Moon position. It can be seen that high water in new moon, quartile and full moon is always different. The Sun movement can be observed from the Sun-up direction on the equatorial line. In addition, it could affect the duration of day and night in some places.

Some of phenomena have also been observed by the Sama tribe or the Orang Bajo hereinafter it becomes the adaptation system to their surroundings. Such adaptation is known as Ethno-Oceanography (Gasalla and Diegues, 2011). Ethno-Oceanography is a sociological study dealing with the environmental phenomena and community interaction with living things or the way of society interacts with surroundings (sea). One of the adaptation systems of the Sama tribe can be seen on the way they set up their house floor from the tidal dynamic. Moreover, it can also be seen from the size of net height of their fish trap construction.

Tidal range determination is a complex mathematical calculation which requires time series data at least 15 moon day (piantan). Technically, high water measurement for tidal range determination is conventionally started out when high water is on maximum movement or during new moon or/and full moon phase. This condition characterized that the measured tidal data input used a lunar system. The same method had been also utilized by the Orang Bajo for time determination of tidal range measurement using Hijra calendar (lunar system). They measured the high water when 15th Sya'ban (Salnuddin et al., 2015a) in when the Moon was the full moon phase.

This short description emerges some questions such as: how variable are the tidal ranges from tidal measurement allocated on Hijra calendar? Is the tidal range in Sya'ban greater than other Hijra months? The questions and objective of this study 
were intended to respond the scientific fundamental of Ethno-Oceanography of the Sama tribe. In order to achieve the objective of this study, the tidal range value in each Hijra month was compared and analyzed statistically.

\section{Materials and Methods}

Station determination was based on data availability and accessibility. The data station was at Bitung which is $01^{\circ} 26.4^{\prime} \mathrm{N}$ and $125^{\circ} 11.6^{\prime} \mathrm{E}$. The selected station was based on the nearest station to Ethno Oceanography of the Sama tribe inhabiting the Southeast Sulawesi (Muna islands), North Maluku (Koyoa and Bacan islands) and Central Sulawesi (Banggai islands). The tidal data was obtained from University of Hawaii Sea Level Center (UHSLC) through downloading from website http://uhslc.soest.hawaii.edu/data/download/rq.

The georgorian data were then converted to Hijra calendar using Accurate Times 5.3.6 software (Odeh, 2013). The software also was used to calculate the sun and month Ephimeries Time (topocentric). Tidal range values were calculated from the harmonic constituent amplitude for determination of mean high water level (MHWL) and highest high water level (HHWL). Tidal range determination used the empirical equation from ICSM PCTMSL (2011) as described below:

$$
\begin{aligned}
& \text { Highest High Water Level }(H H W L)= \\
& M S L+\left(A M_{2}+A S_{2}+A K_{2}+A K_{1}+A O_{1}+A P_{1}\right)
\end{aligned}
$$

$$
\begin{gathered}
\text { Mean High Water Level }(\mathrm{MHWL})= \\
\mathrm{MSL}+\left(\mathrm{AM}_{2}+\mathrm{AK}_{1}+\mathrm{AO}_{1}\right)
\end{gathered}
$$

Where, $\mathrm{MSL}=$ mean sea level; $\mathrm{AM}_{2}=$ tidal amplitude influenced by the Moon's gravity to the orbit and alignment to the Earth's equator; $\mathrm{AS}_{2}=$ tidal amplitude due to solar gravitational effects to the orbit and alignment to the Earth's equator; $\mathrm{AK}_{2}=$ tidal amplitude influenced by the range change of Moon to Earth due to its elliptical orbit; $\mathrm{AK}_{1}=$ tidal amplitude influenced by the declination system of the Moon and Sun; $\mathrm{AO}_{1}=$ tidal amplitude influenced by Moon's declination and $\mathrm{AP}_{1}=$ tidal amplitude influenced by Sun's declination.

Determination of tidal constituent value used the T-Tide (Pawlowicz et al., 2002). Variation of the range in each Hijra month was analyzed using twoway ANOVA (XLSTAT). The significant level was declared at $5 \%(P<0.05)$ and if significant, the data then further analyzed using least significant difference test (LSD).

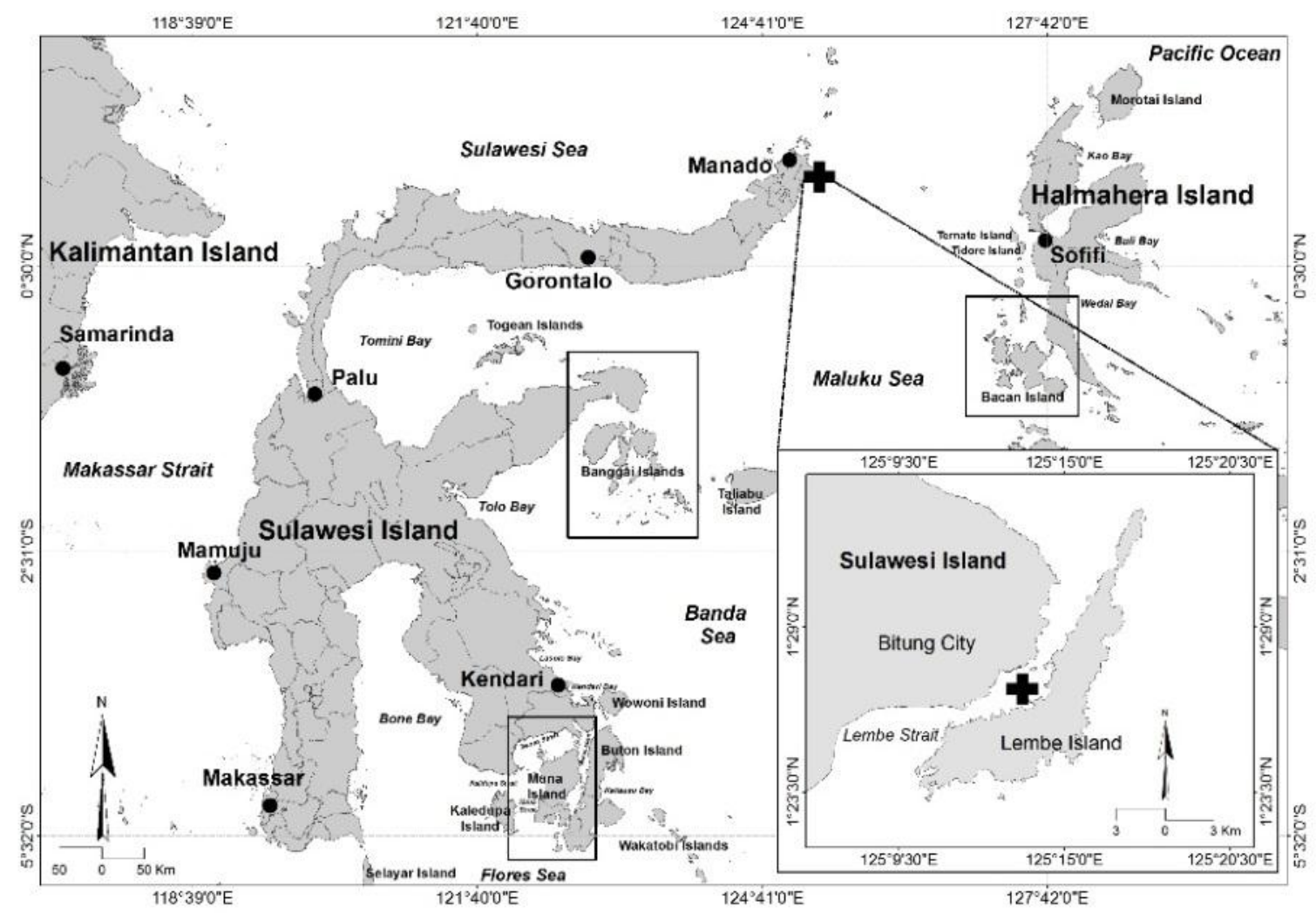

Figure 1. The geographical information and data station of Sama tribe's Ethno Oceanography 


\section{Results and Discussion}

\section{Data distribution and characteristic}

The number of analyzed tidal data was 92,403 started from December 1986 (first Jumadil $1407 \mathrm{H}$ ) to December 2012 (Muharram $1434 \mathrm{H}$ ). From the total data achieved during sixteen years it was only $38.30 \%$ available or ten-year data was unavailable. There was 83 month data used to calculate the tidal harmonic constituent and the tidal range (Figure 2). Distribution of data year number with the same Hijra month was from five to eight years. Using the same data, it was achieved three groups of time series data which was from 16 to 17 months. Those three groups were comprised of $1407 \mathrm{H}$ to $1408 \mathrm{H}$ period which was called data series $1,1429 \mathrm{H}$ to $1430 \mathrm{H}$ period which was called data series 2, and $1430 \mathrm{H}$ to $1431 \mathrm{H}$ which was called data series 3 . The data series were used as control for the calculated result distribution of monthly tidal range.

\section{Amplitude of tidal harmonic constituent}

The results of six tidal harmonic constituents used to calculate tidal range are shown in figure 3. The amplitude of $\mathrm{M}_{2}$ tidal constituent was higher any other five constituents (Salnuddin et al., 2015b). The approximation of amplitude $\mathrm{M}_{2}$ was from 0.33 to $0.38 \mathrm{~m}$ with the mean of $0.35 \pm 0.01 \mathrm{~m}$. The harmonic constituent harmonic that come from sun's gravity effect on daily doubled component $\left(\mathrm{S}_{2}\right)$ was the second largest amplitude and followed by constituent $\mathrm{K}_{1}$ with the mean was $0.24 \pm 0.03 \mathrm{~m}$, $0.20 \pm 0.02 \mathrm{~m}$, respectively. The approximate constituent $\mathrm{S}_{2}(0.17-0.30 \mathrm{~m})$ was larger than that of $\mathrm{K}_{1}(0.16-0.24 \mathrm{~m})$. The lowest harmonic amplitude was constituent $\mathrm{K}_{2}(0.06 \pm 0.01)$ with amplitude approximation was similar to constituent $\mathrm{P}_{1}(0.05-$ $0.08 \mathrm{~m})$. Amplitude mean $\mathrm{P}_{1}$, a constituent influenced by Sun's declination, was larger constituent $(0.01 \mathrm{~m})$ than constituent amplitude $\mathrm{K}_{2}$. The last constituent used in tidal range calculation was constituent $\mathrm{O}_{1}$ which is the effect of Moon's declination. The mean of constituent $\mathrm{O}_{1}$ was $0.12 \pm 0.02 \mathrm{~m}$ with the approximate amplitude of $0.09-0.17 \mathrm{~m}$.

Annual harmonic constituent amplitude (Sa) and semiannual harmonic constituent (Ssa) of the Sun are amplitude of the Sun's declination and range to the Earth. The values can be achieved if the data analyzed with $T_{-}$Tide are available at one year data. The constituent amplitude Sa in $1429 \mathrm{H}-1430$ $\mathrm{H}$ and $1430 \mathrm{H}-1431 \mathrm{H}$ were relatively similar to both of groups that were $0.07 \mathrm{~m}$ and $0.06 \mathrm{~m}$, respectively, even though it was higher than the year $1407 \mathrm{H}-1408 \mathrm{H}(0.05 \mathrm{~m})$. The constituent amplitude Ssa were lower than the constituent amplitude Sa, while the constituent amplitude Ssa in the year $1429 \mathrm{H}$ and $1430 \mathrm{H}(0.002)$ were lower than in the year $1407 \mathrm{H}-1408 \mathrm{H}(0.016 \mathrm{~m})$ and the year $1430 \mathrm{H}$ $1431 \mathrm{H}(0.02 \mathrm{~m})$. Variation of both constituents can be understood due to the Sun distance when the data measurement taking place, or it could be stated that the Sun's position based on data series group in the last two years was closer to the Earth ( $\mathrm{Li}$ et al., 2004).

Based on harmonic constituent calculation from six data series, it was obtained that the amplitude value for each group was relatively similar to the mean of monthly calculated results (83 data). Amplitude for the data series 1 in single component $\left(\mathrm{O}_{1}, \mathrm{P}_{1}\right.$ and $\left.\mathrm{K}_{1}\right)$ was larger $(0.01-0.02 \mathrm{~m})$ than the monthly mean, whereas amplitude for the data series 2 was relatively similar to the monthly mean. And amplitude for the data series $3\left(\mathrm{O}_{1}\right.$ and $\left.\mathrm{P}_{1}\right)$ was smaller than the monthly mean. Harmonic

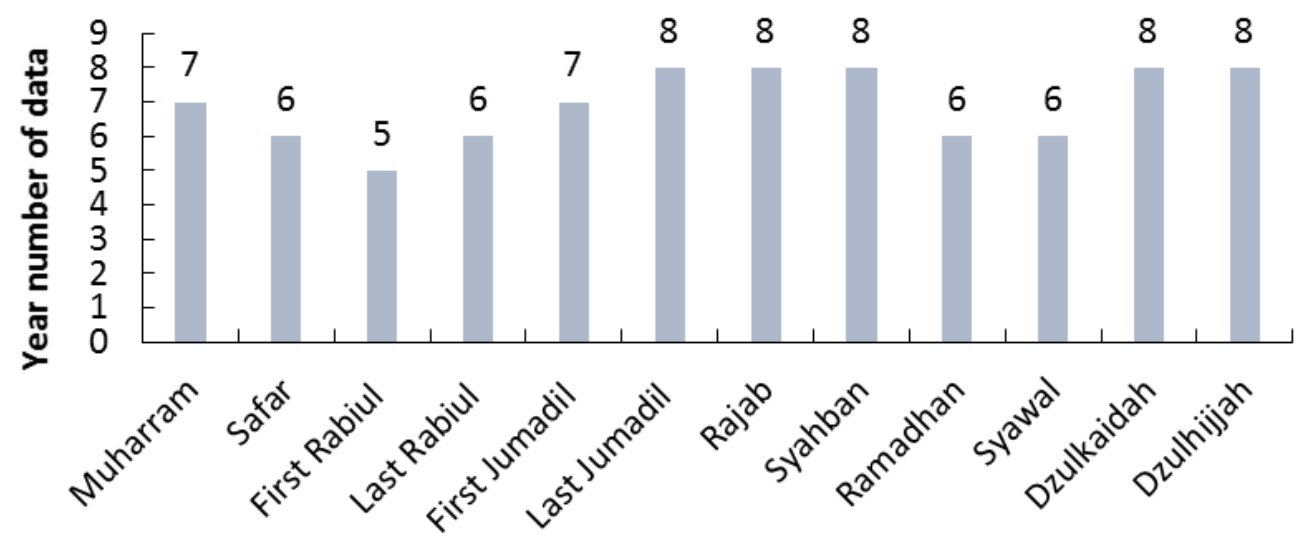

Hijra month

Figure 2. Year number of data in each Hijra month at Bitung Station 


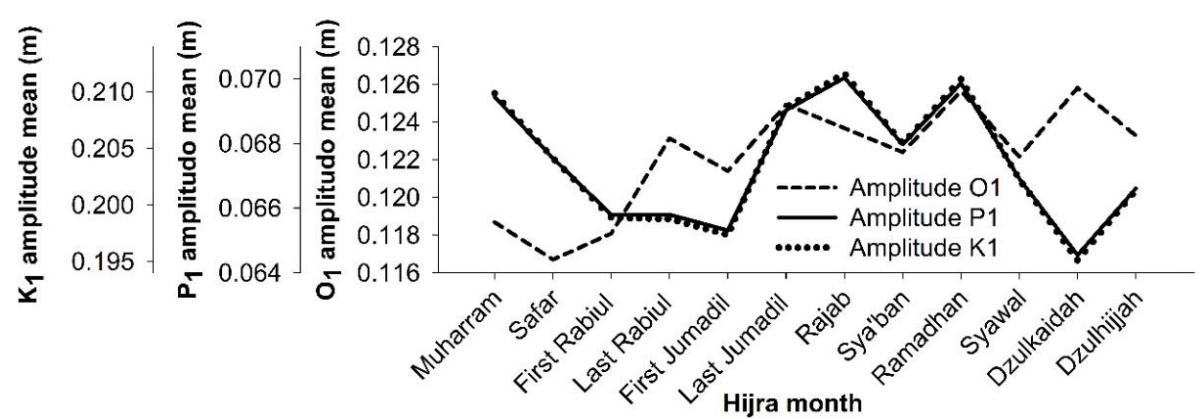

(a) semi diurnal component

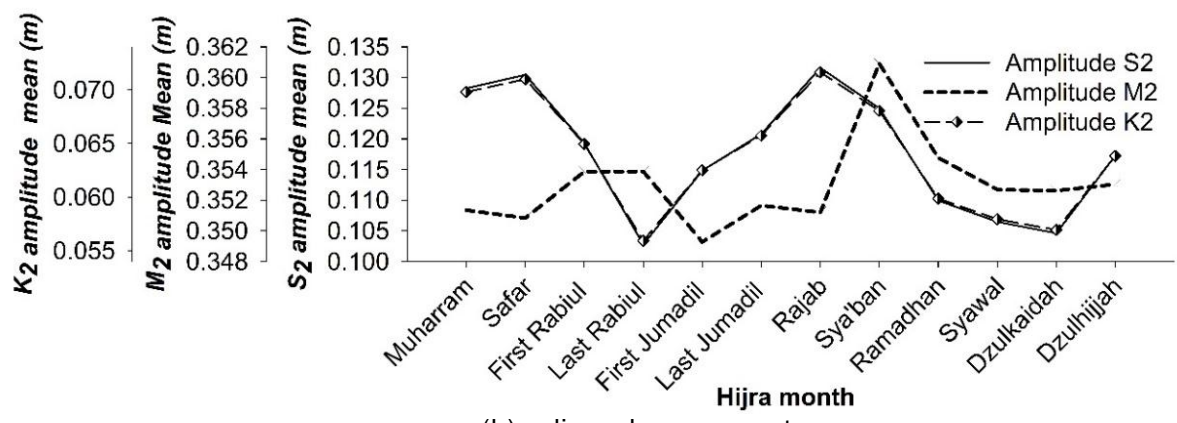

(b) diurnal component

Figure 3. Variation of mean value of the tidal harmonic amplitude based Hijra month at Bitung station

constituent $\mathrm{K}_{1}(0.207 \mathrm{~m})$ was larger than the monthly mean $(0.204 \mathrm{~m})$. The amplitude phenomena from the single component data series also occurred in the double component. Overall, $\mathrm{M}_{2}$ tidal constituent was relatively similar to the monthly mean $(0.35 \mathrm{~m})$, whereas, in the $\mathrm{S}_{2}$ constituent, it was found that only the data series 1 that had similar amplitude with the mean of $0.23 \mathrm{~m}$, and that other two data series had smaller value $(0.22 \mathrm{~m})$ than the monthly mean $(0.24$ $\mathrm{m})$. Constituent amplitude $\mathrm{K}_{2}$ from the data series 1 $(0.07 \mathrm{~m})$ was larger than the monthly mean $(0.06 \mathrm{~m})$, and that other two were relatively similar to the monthly mean.

The graphical pattern of tidal harmonic constituent amplitude in single component (figure 3B) showed upward and downward fashion, even though it was small effect from $\mathrm{O}_{1}$ constituent of first Rabiul to the last month of Hijra year. The amplitude pattern of both $\mathrm{K}_{1}$ and $\mathrm{P}_{1}$ constituents showed $\mathrm{a}$ close pattern. The amplitude of $\mathrm{M}_{2}$ tidal constituent in Sya'ban $(0.36 \mathrm{~m})$ was larger among others, and the lowest amplitude of $\mathrm{M}_{2}$ tidal constituents was found in the first Jumadil or in the fifth month of Hijra with the amplitude was $0.34 \mathrm{~m}$. The results of harmonic constituent amplitude found in this study were in accordance with Rampengan (2013).

\section{Highest High Water level (HHWL) and Mean High Water Level (MHWL)}

Overall, the HHWL found in this study was smaller than the MHWL, where the the MHWL and
HHWL means at Bitung station were 2.16 $\pm 0.03 \mathrm{~m}$ and $2.53 \pm 0.05 \mathrm{~m}$, respectively. The high value of MHWL was in Sya'ban, last Jumadil, Rajab and Ramadhan that were $2.17 \mathrm{~m}$ (Table 1). From those four months, the higher mean of MHWL occurred in Sya'ban. The high value of HHWL was found in Sya'ban and Muharram which have similar value $(2.56 \mathrm{~m})$, but the highest value was found in Rajab $(2.57 \mathrm{~m})$. Standard deviation of MHWL (0.02-0.04 $\mathrm{m})$ was smaller than the standard deviation of $\mathrm{HHWL}$ (0.03-0.09m). Furthermore, small standard deviation of the MHWL was found in five months (41\%), while small standard deviation of the HHWL was found in 3 month (25\%).

Variation of tidal range throughout the data series showed fluctuated MHWL with unstable pattern (Figure 4a). The pattern, as can be seen in the data series 1 (dot line), tended to a upward movement started from Syawal reaching its peak in Muharram, while in data series 2 and 3, it moved down in Muharram. In addition, the MHWL in Sya'ban was relatively on the same altitude from three data series (diamond marker) which are different with Syawal (box marking).

The tidal variation that occurred in MHWL was also observed in HHWL (Figure 4b). By considering the equation used to calculate the HHWL, the change of HHWL was a MHWL change influenced by $\mathrm{S}_{2}, \mathrm{~K}_{2}$ and $\mathrm{P}_{1}$ constituents. On the graphical pattern change of MHWL in the data series 1, the HHWL was closer to other lines, moving down from Syawal to 
the last Rabiul. However, different pattern can be seen in the data series 2 and 3 which tended to rise. The monthly change of tide range was also occurred in Sya'ban, where the high water in MHWL profile conformed one point (closer point), while the high water in HHWL was slightly scattered.

The tidal range value based on harmonic constituent from the three data series group resulted different values. The HHWL of the data series 1 was relatively higher $(2.56 \mathrm{~m})$ than those two data series which were $2.52 \mathrm{~m}$ and $2.50 \mathrm{~m}$. The MHWL was similar to the MHWL and the data series 1 was relatively higher $(2.19 \mathrm{~m})$ than the data series $2(2.16 \mathrm{~m})$ and the data series $3(2.14 \mathrm{~m})$.

\section{HHWL and MHWL deviation}

Deviation of the HHWL was more fluctuated than the MHWL (Figure 4). The smallest deviation of HHWL was in Rajab and was followed by Safar and Sya'ban with deviation of the mean was similar $(0.03 \mathrm{~m})$, while higher deviation with the subsequent order was in the last Jumadil $(0.09 \mathrm{~m})$, first Jumadil $(0.08 \mathrm{~m})$, Ramadhan $(0.06 \mathrm{~m})$ and Dzulhijah (0.06 $\mathrm{m})$.

Graphical pattern from the difference of HHWL and MHWL showed that, in Muharram, Safar, first Rabiul, and last Rabiul, the amplitude effects of $S_{2}, K_{2}$ and $P_{1}$ constituents didn't have strong influence on the HHWL (Figure $5 \mathrm{~b}$ ). It can be seen that the difference of $\mathrm{HHWL}$ and MHWL was similar in that month (gathered point), therefore the additional constituent component from the MHWL constituent value resulted small impact. Different impact was showed in the other months that the graphical pattern from the difference of mean, minimum and maximum in every tidal range was isolated each other. The higher the difference of $\mathrm{HHWL}$ and MHWL is, the greater the contribution of $\mathrm{S}_{2}, \mathrm{~K}_{2}$ and $\mathrm{P}_{1}$ constituents. Moreover Figure 5 showed that the range increased largely during the fifth and sixth month of Hijra year and then decreased in the next two months and tended to increase thereafter.

The results of the tidal range difference of HHWL on MHWL which is influenced by $S_{2}, K_{2}, P_{1}$ constituent effects are shown in figure 6 . The downward pattern occurred for five to six months when it was higher in the first year than in the last year. In addition, the upward pattern occurred for two to three months which was in opposed manner to the downward pattern. The variation effect of $S_{2}$, $\mathrm{K}_{2}$, and $\mathrm{P}_{1}$ constituents occurred in minimum turning point, where the last two time series groups showed relatively similar pattern in which the movement to the minimum turning point in the first year was the first and last Jumadil (rectangle mark), while the movement in the last year was in Dzulhijjah (circle mark). However, in the data series 1, different occurrence was observed where the minimum point in the last year was in Syawal, while the movement to the minimum point in the first year was in the first Rabiul.

The relatively stable pattern in figure 6 showed information that different tidal range change occurred every three and six month intervals. Recall that $\mathrm{S}_{2}$ tidal constituent is a constituent exerted by the Earth's rotation to the Sun and, in addition, $\mathrm{K}_{2}$ constituent is an amplitude modulation and frequency (resultant) as a consequence of Moon's and Sun's declination to the Earth (Bursa, 1987).

Table 1. Mean, max, min and deviation of MHWL and HHWL based on Hijra month at Bitung Station

\begin{tabular}{|c|c|c|c|c|c|c|c|c|c|}
\hline \multirow{2}{*}{ Hijra Month } & \multicolumn{4}{|c|}{ MHWL (m) } & \multicolumn{4}{|c|}{ HHWL (m) } & \multirow{2}{*}{$\begin{array}{l}\text { Data number } \\
\text { (year) }\end{array}$} \\
\hline & Mean & Max & Min & Dev & Mean & Max & Min & Dev & \\
\hline Muharram & 2.16 & 2.22 & 2.09 & 0.04 & 2.56 & 2.61 & 2.49 & 0.05 & 7 \\
\hline Safar & 2.15 & 2.20 & 2.10 & 0.04 & 2.55 & 2.60 & 2.52 & 0.03 & 6 \\
\hline First Rajab & 2.15 & 2.20 & 2.10 & 0.04 & 2.52 & 2.55 & 2.46 & 0.04 & 5 \\
\hline Last Rajab & 2.16 & 2.21 & 2.09 & 0.04 & 2.49 & 2.53 & 2.42 & 0.04 & 6 \\
\hline First Jumadil & 2.15 & 2.19 & 2.09 & 0.03 & 2.51 & 2.63 & 2.39 & 0.09 & 7 \\
\hline Last Jumadil & 2.17 & 2.21 & 2.13 & 0.03 & 2.54 & 2.65 & 2.43 & 0.09 & 8 \\
\hline Rajab & 2.17 & 2.20 & 2.15 & 0.02 & 2.57 & 2.61 & 2.53 & 0.03 & 8 \\
\hline Sya'ban & 2.17 & 2.20 & 2.15 & 0.02 & 2.56 & 2.60 & 2.52 & 0.03 & 8 \\
\hline Ramadhan & 2.17 & 2.20 & 2.14 & 0.03 & 2.52 & 2.59 & 2.46 & 0.06 & 6 \\
\hline Syawal & 2.16 & 2.18 & 2.13 & 0.02 & 2.50 & 2.54 & 2.44 & 0.04 & 6 \\
\hline Dzulkaidah & 2.16 & 2.19 & 2.13 & 0.02 & 2.49 & 2.57 & 2.45 & 0.04 & 8 \\
\hline Dzulhijjah & 2.16 & 2.19 & 2.13 & 0.02 & 2.53 & 2.60 & 2.44 & 0.06 & 8 \\
\hline Mean & 2.16 & 2.20 & 2.12 & 0.03 & 2.53 & 2.59 & 2.46 & 0.05 & \\
\hline
\end{tabular}


Moreover, $\mathrm{P}_{1}$ constituent is a tidal harmonic constituent exerted by Sun's declination. Considering those factors, it could be stated generally that $S_{2}, K_{2}$ and $P_{1}$ constituents were the description of Moon, Sun and Earth position. By using simple approach to the angle distribution in lunar solar systems and Moon-Sun declination, graphical pattern in figure 6 was a translation of the Earth's closest range to the Sun and Moon (Wilhelm et al., 1997; and Mawdsley et al., 2015).

Annual cycle of the Earth to the Sun and the Moon to the Earth which were in the greatest distance occurred in beginning of second year. Distributed space allocation of both systems which were further referred as the name of month was a translation of the acquired angle for one year cycle. Opposite realm movement caused the declination (nearest distance) to the Earth, based on georgorian, it was in June and October, while in Hijra calendar it was in Rabiul and Syawal. Considering $K_{2}$ and $P_{1}$ constituents are the declination factor of Moon and Sun, the coincidence of both distributional systems will be moved around $\pm 10^{\circ}$ per year. That would mean that if it was counted down from $1430 \mathrm{H}$ to $1407 \mathrm{H}$ (23 years), it had moved about $230^{\circ}$ or moved the declination time about $7.6(\approx 8)$ Hijra months. Therefore, if the declination in $1430 \mathrm{H}$ occurred in the first Jumadil, then the declination in $1407 \mathrm{H}$ would be in Syawal.

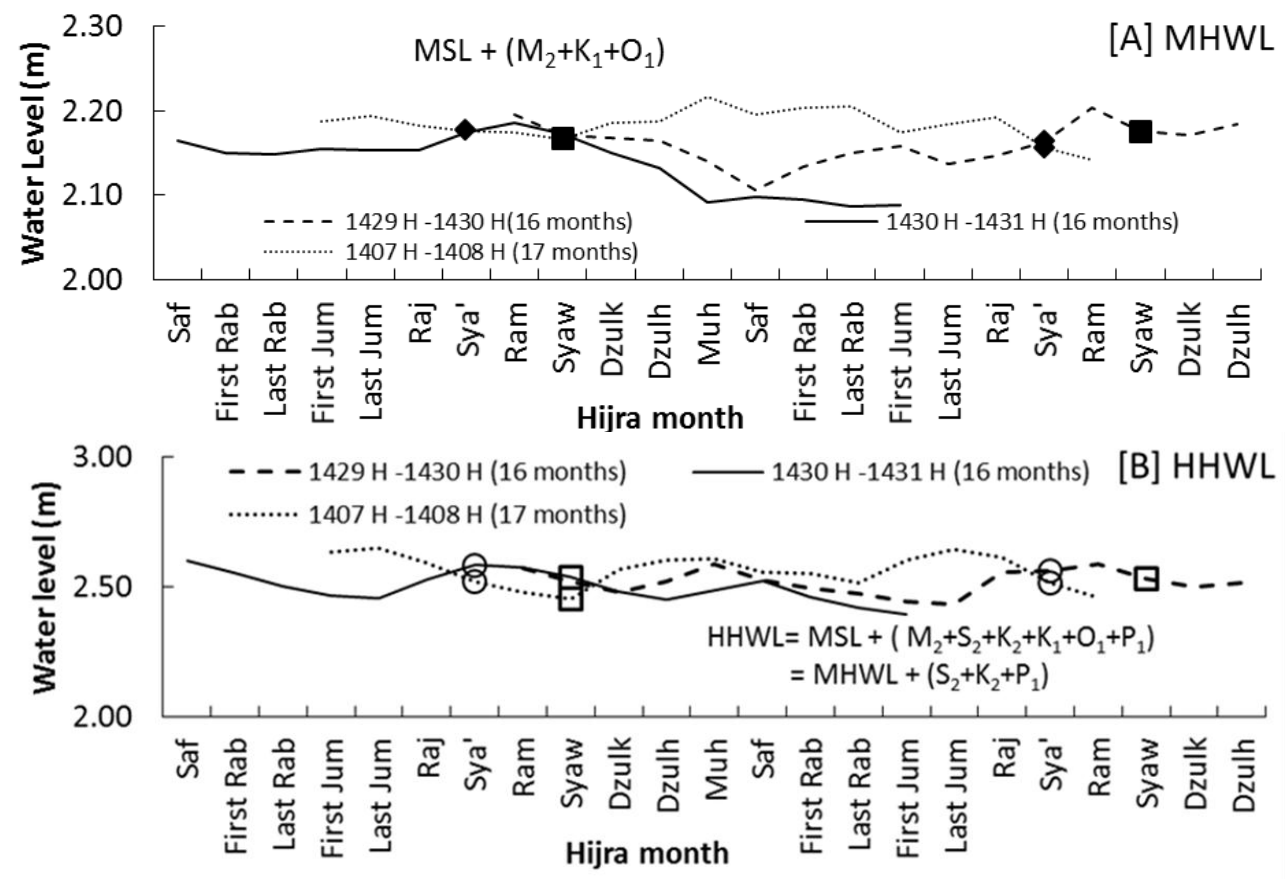

Figure 4. Tidal range distribution of a) MHWL and b) HHWL
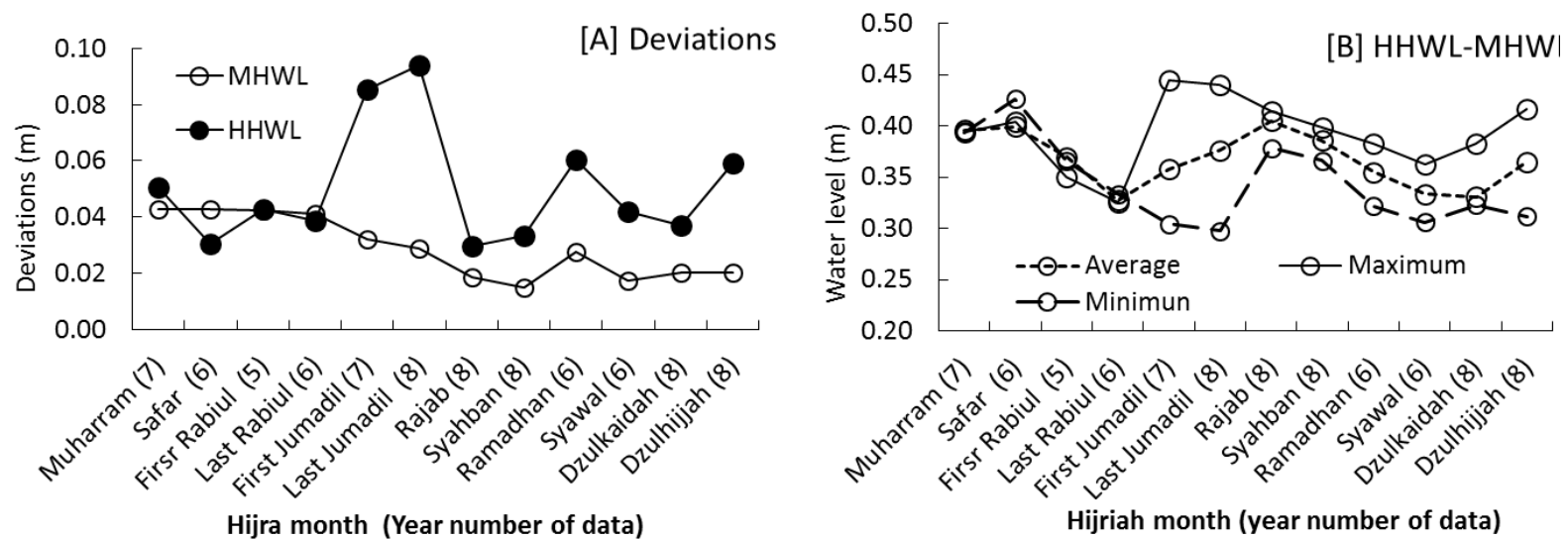

Figure 5. Graphical pattern at Bitung station. a). tidal deviation and b). tidal differen 


\section{ANOVA of tidal range}

Statistical data analysis of MHWL and HHWL was conducted to find out whether there is or not significant difference among month means of resulted tidal range. The least square mean of MHWL was 2.15-2.18 with the mean was $2.17 \pm$ 0.009 , while the least square mean of HHWL was 2.49-2.61 with the mean was $2.54 \pm 0.037$. There was no significant difference of the MHWL mean throughout Hijra month with Fvalue $0.4753\left(R^{2}=\right.$ 0.0982). It means that the month effect was the same on MHWL througout Hijra months $(P<0.909)$. Month group on the MHWL was under the same notation (Figure 8). There was significant difference of month effect on the HHWL from five year data $(P<0.006)$ (Figure 7$)$.

The square means of HHWL in Sya'ban, Dzulhijjah and first Jumadil were 2.54-2.55 showing different superscript (A, B, C, D and E). The square mean in other months has smaller superscript than three months before. In Ramadhan, first Rabiul and Safar were in 4 combination superscripts. Muharram were in three combination superscripts (C, D and $E)$, and Safar were in three combination superscripts $(A$,
B and C). Last Rabiulfigure and Rajab were in two combination superscripts which last Rabiul was in A and $B$ superscripts and Rajab was in D and $E$ superscript. The month with one superscript was Dzulkaidah and last Jumadil which was $A$ and $E$. ANOVA results showed that there is no significant effect of month on MHWL value in Hijra calendar. Non significant effect found in this study could be influenced by low effect of $M_{2}, K_{2}$ and $O_{1}$ constituents throughout Hijra month. In contrast, the month effect has significant influence on HHWL in where the last Jumadil was the highest value and Dzulkaidah was the lowest value.

\section{Tidal range variation and ethno-oceanography of the Sama Tribe}

High water measurement for tidal range determination conducted by the Sama tribe in Sya'ban was scientific evidence (Salnuddin et al., 2015a). Generally, the ability of the Sama tribe to see the natural change as a cycle described their understanding that the length of a day in hijra calendar system was relatively stable in month $(29 / 30)$ and year period (355/356). Their understanding was also exposed on the variation of

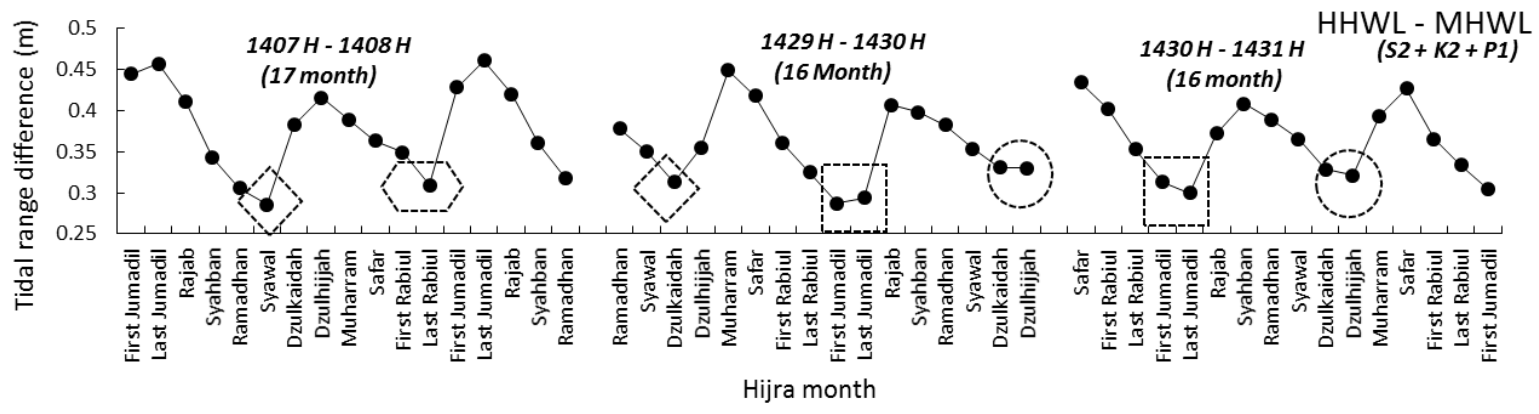

Figure 6. Variation of difference value between HHWL and MHWL at Bitung station.

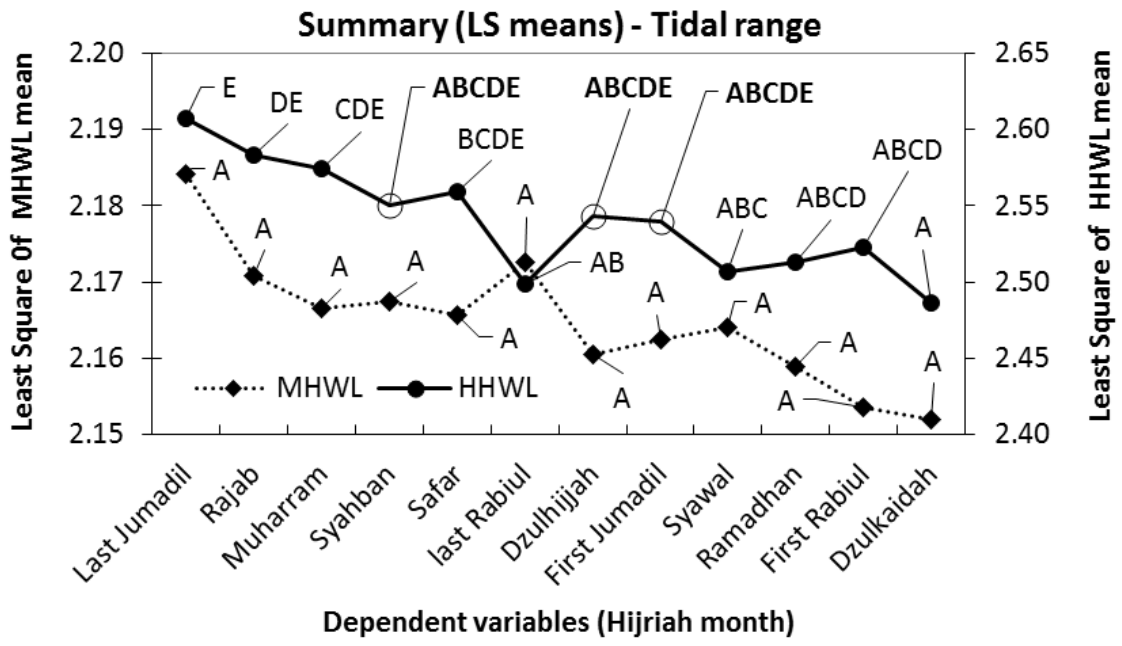

Figure 7. Least significant Difference of month effect throughout Hijra calendar on MHWL and HHWL at Bitung Station. 
high water in every moon phase (Salnuddin, 2016). The related issues supporting the EthnoOceanography as scientific evidence were based on some analyses, such as (1) The single component constituent ( $\mathrm{K}_{1}, \mathrm{O}_{1}$ and $\left.\mathrm{P}_{1}\right)$, however, which is a not maximum value in Sya'ban, resulted considerable high amplitude which was $\approx 2 / 3$ of maximum amplitude occurred in Sya'ban; (2) High water deviation of HHWL and MHWL in Sya'ban was relatively small; (3) Influence of $S_{2}, K_{2}$ dan $P_{1}$ constituents on HHWL was relatively small as a difference value on MHWL. The difference of both tidal range and minimum high water was 1:3 on its mean. This indicated that the mean of $\mathrm{HHWL}$ or MHWL on maximum and minimum values of each tidal range contributed about one portion above the average line, as maximum value and three portions below the average line, as minimum value; (4) The composition of Harmonic constituent (HHWL and $\mathrm{MHWL}$ ) and range difference showed that $\mathrm{S}_{2}, \mathrm{~K}_{2}$ and $\mathrm{P}_{1}$ constituents affected high water fluctuation (HHWL). Moreover, by considering the velocity of $\mathrm{S}_{2}$ and $\mathrm{K}_{2}$ constituent about $30^{\circ}$ per Sun's hour, a high water change that was influenced by $S_{2}$ and $K_{2}$, occurred in monthly period. This situation described that a change of tidal range which is different with $\mathrm{P}_{1}$ constituent resulted a change in every fifteen days (half a month) as a consequence of $\mathrm{P}_{1}$ velocity which is $15.04^{\circ}$ per Sun's hour; and (5) Sya'ban was significantly different on $\mathrm{HHWL}$

\section{Conclusion}

The tidal range values of Sya'ban were relatively more stable and lower deviation than the other months. The water range of Sya'ban was relatively higher than the other months. MHWL was not significantly different, whereas HHWL was significantly different in every hirja month. Sya'ban, Dzuhijjah and the first Djumadil was significantly different on HHWL.

\section{References}

Bursa, M. 1987. The tidal evolution of the EarthMoon system. Bull. Astronom. Ins. Czechoslovakia. 38:321-324

Butikov, El. 2002. A dynamical picture of the oceanic tides. American J. Physics. 70(10):1001-1011. doi: http://dx.doi.org/10.1119/1.1498858

Gasalla, M.A. \& Diegues, A.C. 2011. People's seas: "Ethnooceanography" as an interdisciplinary means to approach marine ecosystem change.
World fisheries: a social-ecological analysis. Wiley-Blackwell, Oxford, UK.120-136

ICSM-PCTMS. 2011. Australian Tides Manual SP9 V4.2. Intergovernmental Committee of Surveying and Mapping - Permanent Committee On Tides And Mean Sea Level.

Li, P., Li, L., Zuo, J., Zhao, W. \& Chen, Z. 2004. Tidal analysis of high and low water data. J. Ocean University of China. 3(1):10-16. doi: 10.1007/s11802-004-0002-2

Mawdsley, R.J., Haigh, I.D. \& Wells, N.C. 2015. Global secular changes in different tidal high water, low water and range levels. Earth's Future. 3(2):66-81. doi: http://dx.doi.org/10. 1002/2014EF000282

Odeh, M. 2013. Accurate Times 5.3.6 software, Islamic Crescents' Observation Project (ICOP). .

Pawlowicz, R., Beardsley, B. \& Lentz, S. 2002. Classical tidal harmonic analysis including error estimates in MATLAB using T_TIDE. Computers \& Geosciences. 28(8):929-937. doi: 10.1016 /S0098-3004(02)00013-4

Rampengan, R. 2013. Amplitudo konstanta pasang surut M2, S2, K1 dan 01 di perairan sekitar Kota Bitung Sulawesi Utara. J. IImiah Platax. 9(1):27-30

Salnuddin. 2016. Penentuan Awal Bulan Baru Penanggalan Hijriah Berdasarkan Pendekatan Ethnooceanography dan Ethnoastronomy Bogor: Disertasi-Institut pertanian Bogor.

Salnuddin, Nurjaya, I. W., Jaya, I. \& Natih, N.M. 2015a. Variasi Amplitudo Konstituen Harmonik Pasang Surut Utama di Stasiun Bitung, Sulawesi Utara. IImu Kelautan. 20(2):73-86. doi: 10.14710/ik.ijms.20.2.73-86.

Salnuddin, Nurjaya, I.W., Jaya, I. \& Natih, N.M. 2015b. Perhitungan tunggang air pasang surut berdasarkan kearifan lokal masyarakat Suku Sama di Wilayah Timur Indonesia. J. IImu dan Teknologi Kelautan Tropis. 7:347-363

Souchay, J., Mathis, S. \& Tokieda, T. 2012. Tides in astronomy and astrophysics. Springer.

Wilhelm, H., Zürn, W. \& Wenzel, H.G. 1997. Tidal phenomena. Lecture Notes in Earth Sciences, Berlin Springer Verlag. 66 